\title{
Atmospheric particulate matter in Tarnów City (Southern Poland) - short time investigation of a space-time variability in the winter of 2019
}

\author{
Marek Chyca, ${ }^{a, *}$ Mariusz Klichª, Sabina Klich ${ }^{b}$, Patrycja Żelazo ${ }^{a}$, Agnieszka Ciężadło ${ }^{a}$, Paweł Żeleźnika, \\ Paweł Partyńskia
}

a State Higher Vocational School in Tarnów, Mickiewicza 8, 33-100 Tarnów, Poland

b Instiute of Botany, Jagiellonian University, Gronostajowa 3, 30-387 Kraków, Poland

\section{Article history:}

Received 5 June 2019

Received in revised form

11 July 2019

Accepted 11 July 2019

Available online 11 July 2019

\begin{abstract}
Tarnów is a city where air pollution is a major problem during the wintertime. An acceptable level of PM2.5 and PM10 concentrations are exceeded very often. The main reason of this situation is individual housing and their heat system based on ineffective old units based on hard coal and sometimes even people use waste as a fuel. The city has two air quality monitoring stations and a private network for measurements of particulate matter. However, there is still a lack of information on air quality in some areas of the city. For obtaining full information on the air quality in Tarnów, readings from the monitoring station and field measurements were carried out. The obtained information allowed to determine which areas of the city are most exposed to the occurrence of smog in the heating season. So far, air quality measurements in Tarnów have not been conducted at the same time for so many collections.The most polluted air occurs in Krzyż District but air quality should be improved in all city. The best air quality has been observed for locations where heat is available from municipal heating plant e.g. Słoneczna Str. Presented research work shows that air quality in Tarnów City is very unhealthy because of particulate matter pollution. In the winter time the main problem is too high concentration of PM2.5, but also PM10 concentration. Those parameters are very frequently exceeded. The worst air quality occurs in the evenings ( 8 p.m.), but in the mornings ( 8 a. m.) air quality is highly polluted too. When air quality in Tarnów City is bad situation concerns all localisations. The similar situation is observed when air quality is good or acceptable. The main conclusion is that for locations where heat is available from heat plant is not generated individually by domestic sources, the situation is the most comfortable. Our investigation covered short period, but it is preliminary study and this important issue will be continued in the future.
\end{abstract}

Keywords: Airborne pollution, particulate matter, heating season, smog

\section{Introduction}

Nowadays, the improvement of air quality in Poland is a key point of both local authority and the central government. Air quality improvement programs are focused mainly on particulate matter pollution and result from the fact that air quality in our country is considered one of the worse in Europe [1]. Airborne pollutants have a significant impact on the morbidity of people for many diseases referred to as civilization diseases such as cancer, respiratory and circulatory system diseases and allergies [2]. Particulate matter (PM) with a size $<20 \mu \mathrm{m}$ contained in the air are not only physical impurities but also a carrier of chemical contaminants such as: heavy metals (mainly lead and mercury), polycyclic aromatic hydrocarbons (PAHs) [3], polychlorinated dibenzo-p-dioxins and furans (PCDDs, PCDFs - dioxins) [4]. In the past in Poland, the quality of air in relation

*Corresponding author: mrsch@tlen.pl to dust was initially measured by the amount of annual dust fall. The change in the measurement methodology consisting in the measurement of PM10 dust fraction was caused by the need to implement Polish legislation to the requirements of the European Union [5]. Detailed guidelines are specified in the Regulation of the Minister of Environment of June 6, 2002 on acceptable levels of certain substances in the air, alarm levels of certain substances in the air and margins of tolerance for acceptable levels of certain substances [6]. In 2015, the requirements regarding the level of fine dust in air were introduced in Poland (PM2.5) and a limit value of $25 \mu \mathrm{g} / \mathrm{m}^{3}$ was temporarily set. According to the Regulation of the Polish Minister of the Environment a new requirement will apply from $1^{\text {st }}$ January 2020, the PM2.5 content in atmospheric air should not exceed $20 \mu \mathrm{g} / \mathrm{m}^{3}$ [7]. At present, the basic air quality problems in Poland are frequent exceedances of PM2.5 dust concentration standards. According to the same regulation PM10 concentration should not exceed $50 \mu \mathrm{g} / \mathrm{m}^{3}$ (it is allowed by law when average day concentration 
of PM10 is higher than $50 \mu \mathrm{g} / \mathrm{m}^{3}$, but 35 times per year only). Average concentration in a year should not exceed $40 \mu \mathrm{g} / \mathrm{m}^{3}$. Air quality depends on the kind and intensity of emissions in a given area, meteorological and topographic conditions of the area. Tarnów City has similar problem like many Polish cities, the problem is winter smog. There are still many low-efficient coal boilers in Tarnów City (Fig. 1) and they cause frequent exceedances of air quality standards.

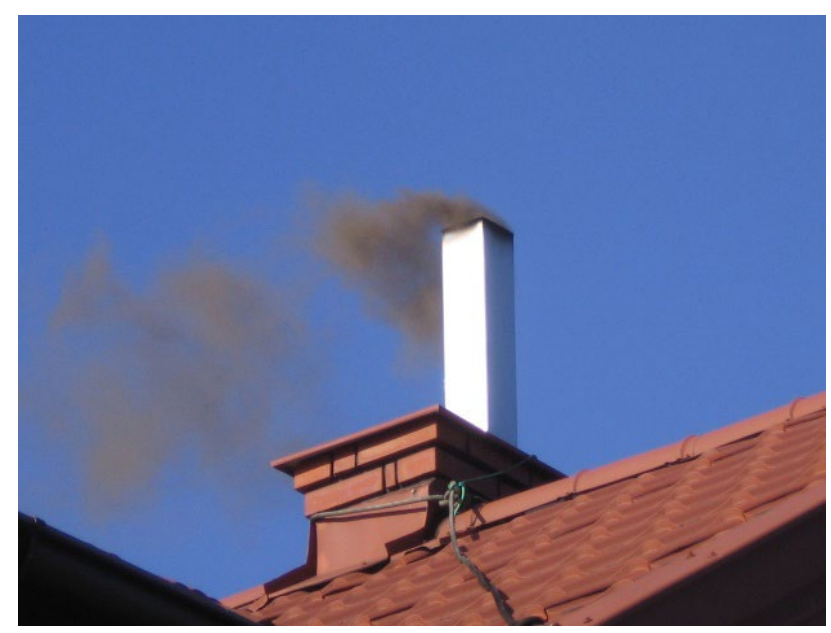

Figure 1. Residential emission - the main source of smog in Poland (fot. M.Chyc)

The basic monitoring data were collected from automated air quality stations. There are two air monitoring stations in Tarnów City as part of the State Environmental Monitoring (WIOŚ). The rules for conducting measurements as well as the criteria for the location of measurement points are regulated by the Regulation of the Minister of the on the assessment of levels in the air [8]. The growing interest in the issues of air quality in society and the feeling that due to the large distance from the monitoring station from the place of residence caused the development of private air monitoring networks. This initiative, although it is a manifestation of the increased environmental awareness of society, in the opinion of specialists cannot be treated equally with the data obtained from official source. Objections concern the quality of measurements carried out by private users, usually using "low-cost" equipment, which do not have calibration certificates and metrological supervision, as is the case for accredited measurements. Our investigation based on few types of data sources and this issue can cause a significant error, too. It cannot be ruled out that some of these measurements may be burdened with even a gross error. Despite these reservations, and taking into account the imperfection of the adopted measurement methodology, comparative studies on air pollination at various locations in Tarnów City on 18-24 February 2019 have been conducted. The presented work is a preliminary study into the variability of spatiotemporal dust pollution in Tarnów City, their causes and trends. Nowadays in Poland is huge effort focused on air improvement and Polish society is aware of the need for changes in this issue [9].

Tarnów City is located in the Southern Poland, in the Tarnów County, in the Małopolska Voivodship. Based on various data, over 20 Polish cities are among the first 50 cities characterized by the most heavy black smog in the EU. Despite the fact that Tarnów City it is not a large city it all, but it is characterized as one of the most polluted city in Poland during winter time. Therefore, Tarnów City is a suitable area for investigation of the daily dynamics and spatial variability of PM changes for an average-sized city. According to Matuszkiewicz "Geo-regionalization of Poland" [10], the area is located in the section of the south-Polish highlands, the land of the Sandomierz gorge, the Niepołomice-Tarnów region, the Tarnów sub-district. Tarnów City covers an area of $72.38 \mathrm{~km}^{2}$. Officially the city is inhabited by 110644 peoples [11], and municipal rights were earned very early, it took place in 1330 [12]. The city has an irregular shape, there maximum length is $11 \mathrm{~km}$ in the $\mathrm{W}$-E axis and maximum width $8 \mathrm{~km}$ in the N-S axis. Tarnów City in the $19^{\text {th }}$ and $20^{\text {th }}$ centuries developed as one of the most important industrial centre in Poland. Western part of city is industrialized area, mainly covers by large chemical company - Azoty Group. In addition, the city consists of detached houses, there are few block of flats, other industrial and suburban areas, as well as woody and ruderal areas. The northern border of the city is one of the busiest national highways number A4.

Physiographically Tarnów is diverse and valuable in aspects of nature. Its southern region belongs to the Carpathians chain with their last hill - St. Martin Mount, the northern region is located in the part of Sandomierz Basin.

The western border of Tarnów is the Dunajec River. There is a valuable area of the Natura 2000 Network Dolny Dunajec (PLH120085). The Biała Tarnowska River divides city center, which, within few kilometers to the southern part of the city, constitutes the Natura 2000 Network of Biała Tarnowska (PLH120090) [13], [14]. The Dunajec River and its Valley is a national rank ecological corridor. The Biała Tarnowska River and its valley is a local ecological corridor [15].

\section{Materials and Methods}

Dust measurements were made with LINECOMP dust meters model WP 6300 and Dienmern model WP 6910. The measurements were carried out in the normal range of use, each time collected ten results, after that calculated mean value. Data from the State Environmental Monitoring System [16] were obtained and data from commercial stations through the Internet [12], international stations code PL0502A and PL0647A. The scope of investigation covers period 18.02-24.02.2019 and contains manual measurements of dust concentration in 7 representative locations, additional data from 8 measurement points downloaded 
from the Internet (Table 1). In the same time meteorological data (temperature, pressure, wind force, wind direction, relative humidity) were collected. The meteorological data has been averaged and presented in Table 2.

\section{Results and Discussion}

\section{Manual measurement points localization}

Table 1 shows the location of the PM concentration measurement points, and then each position is shortly described, there are given the location names and GPS coordinates. Positions are located on symmetrical layout, however, some modification were used to cover various field factors that may impact on air quality.

Table 1. Localization of own measurements points

\begin{tabular}{|c|c|c|c|c|}
\hline Measurement localization & Localization in Tarnów City & Latitude & Longitude & Altitude (m a.s.l) \\
\hline P1 & City Market Sq. & $50^{\circ} 00^{\prime} 46.15^{\prime \prime} \mathrm{N}$ & $20^{\circ} 59^{\prime} 19.33^{\prime \prime} \mathrm{E}$ & 225 \\
\hline $\mathrm{P} 2$ & Słoneczna Str. & $50^{\circ} 01^{\prime} 02.77^{\prime \prime} \mathrm{N}$ & $21^{\circ} 00^{\prime} 20.69^{\prime \prime} \mathrm{E}$ & 222 \\
\hline P3 & Krzyż Qr. & $50^{\circ} 02^{\prime} 44.35^{\prime \prime} \mathrm{N}$ & $20^{\circ} 59^{\prime} 42.08^{\prime \prime} \mathrm{E}$ & 246 \\
\hline P4 & Krakowska Str. & $50^{\circ} 00^{\prime} 36.12^{\prime \prime} \mathrm{N}$ & $20^{\circ} 58^{\prime} 42.62^{\prime \prime} \mathrm{E}$ & 203 \\
\hline P5 & Mościckiego Str. & $50^{\circ} 00^{\prime} 45.64^{\prime \prime} \mathrm{N}$ & $20^{\circ} 58^{\prime} 13.62 ” \mathrm{E}$ & 200 \\
\hline P6 & Kwiatkowskiego Str. & $50^{\circ} 00^{\prime} 58.85^{\prime \prime} \mathrm{N}$ & $20^{\circ} 55^{\prime} 47.79^{\prime \prime} \mathrm{E}$ & 195 \\
\hline P7 & St. Marcin Mt. & $49^{\circ} 59^{\prime} 40.17^{\prime \prime} \mathrm{N}$ & $20^{\circ} 59^{\prime} 58.133^{\prime \prime} \mathrm{E}$ & 220 \\
\hline $\mathrm{A} 1$ & Głowackiego Str. & $50^{\circ} 00^{\prime} 30.69^{\prime \prime} \mathrm{N}$ & $20^{\circ} 57^{\prime} 55.22^{\prime \prime} \mathrm{E}$ & 198 \\
\hline A2 & Grottgera Str. & $50^{\circ} 00^{\prime} 58.33^{\prime \prime} \mathrm{N}$ & $20^{\circ} 58^{\prime} 45.88^{\prime \prime} \mathrm{E}$ & 201 \\
\hline A3 & Lema Str. & $50^{\circ} 01^{\prime} 39.74{ }^{\prime \prime} \mathrm{N}$ & $20^{\circ} 58^{\prime} 57.75^{\prime \prime} \mathrm{E}$ & 201 \\
\hline A4 & Lwowska Str. & $50^{\circ} 00^{\prime} 45.66^{\prime \prime} \mathrm{N}$ & $21^{\circ} 01^{\prime} 24.69$ '” & 218 \\
\hline A5 & Krakowska Str., nr 5 & $50^{\circ} 00^{\prime} 41.49^{\prime \prime} \mathrm{N}$ & $20^{\circ} 59^{\prime} 01.70^{\prime \prime} \mathrm{E}$ & 215 \\
\hline A6 & Dąbrowskiego Str. & $50^{\circ} 00^{\prime} 34.72^{\prime} \mathrm{N}$ & $20^{\circ} 59^{\prime} 37.08^{\prime \prime} \mathrm{E}$ & 205 \\
\hline W1 & Sitki Str. & $50^{\circ} 01^{\prime} 05.75^{\prime \prime} \mathrm{N}$ & $20^{\circ} 59^{\prime} 33.29^{\prime \prime} \mathrm{E}$ & 216 \\
\hline W2 & Bitwy pod Studziankami Str. & $50^{\circ} 01^{\prime} 12.61^{\prime \prime} \mathrm{N}$ & $21^{\circ} 00^{\prime} 15.00^{\prime \prime} \mathrm{E}$ & 243 \\
\hline
\end{tabular}

Short description of manual measurement points:

P1 - located in the historical "heart" of Tarnów - on the market. The market is surrounded by a lot of old tenement buildings, mostly heated with coal stoves. This area is partly inhabited by retirees and the poor who use low-quality coal and even municipal waste (prohibited by law).
P2 - located on the edge of the largest residential area, where exist a lot of buildings blocks. There are mainly four-storey and eleven-storey blocks built between 1980 and 2005. These buildings are heated by a municipal heating system (Miejskie Przedsiębiorstwo Energetyki Cieplnej), which supplies hot water heated by natural gas to buildings. The municipal heat system generates energy from hard coal, but power plant is far away from city center. There are few detached houses with a diverse heating system (coal and natural gas). Directly at the station is located a busy four-lane street.

P3 - located in the centre of a large housing area consisting of several hundred detached- houses. Some of the buildings were built over 60 years ago. Most of them are heated with hard coal, wood, and even with the addition of municipal waste. There are still many people who are characterized by low ecological awareness. On this area the buildings are serried, and there is heavy car traffic only along the main street leading to the downtown.

P4 - located in the city centre, at Krakowska Street leading from the main railway station to the market square. The street is surrounded by a number of old tenement houses mostly heated 
with low effective coal stoves, there is heavy car traffic.

P5 - located near the city centre, at Szujskiego Street. It is one of the main communication routes in the W-E axis in Tarnów. The point is surrounded by old tenements and detached houses. Detached housing of a similar type as described in position 3, however, less numerous. On this area the buildings are serried and there occurs heavy car traffic.

P6 - located in the western part of the city in an industrial area near large chemical plants of Azoty Group. Sampling point is located near Kwiatkowskiego Street and it is a busy road, but it is far away from individual coal powered houses. Quite near this position is dolomite milling plant and it may be source of mineral dust in the air. Position P6 represents both, industrial and road traffic pollutions.
P7 - located in the southern part of the city on the edge of a large housing area where are a lot of detached houses. The buildings are not as serried as in positions P3 and P5, and they are modern and some of them are heated with natural gas. Near the P7 position there are the slopes of the St. Marcin Mountain and the four-lane city bypass.

The localization of all measurement points illustrate Figure 2 where they are pointed on the map of Tarnów City.

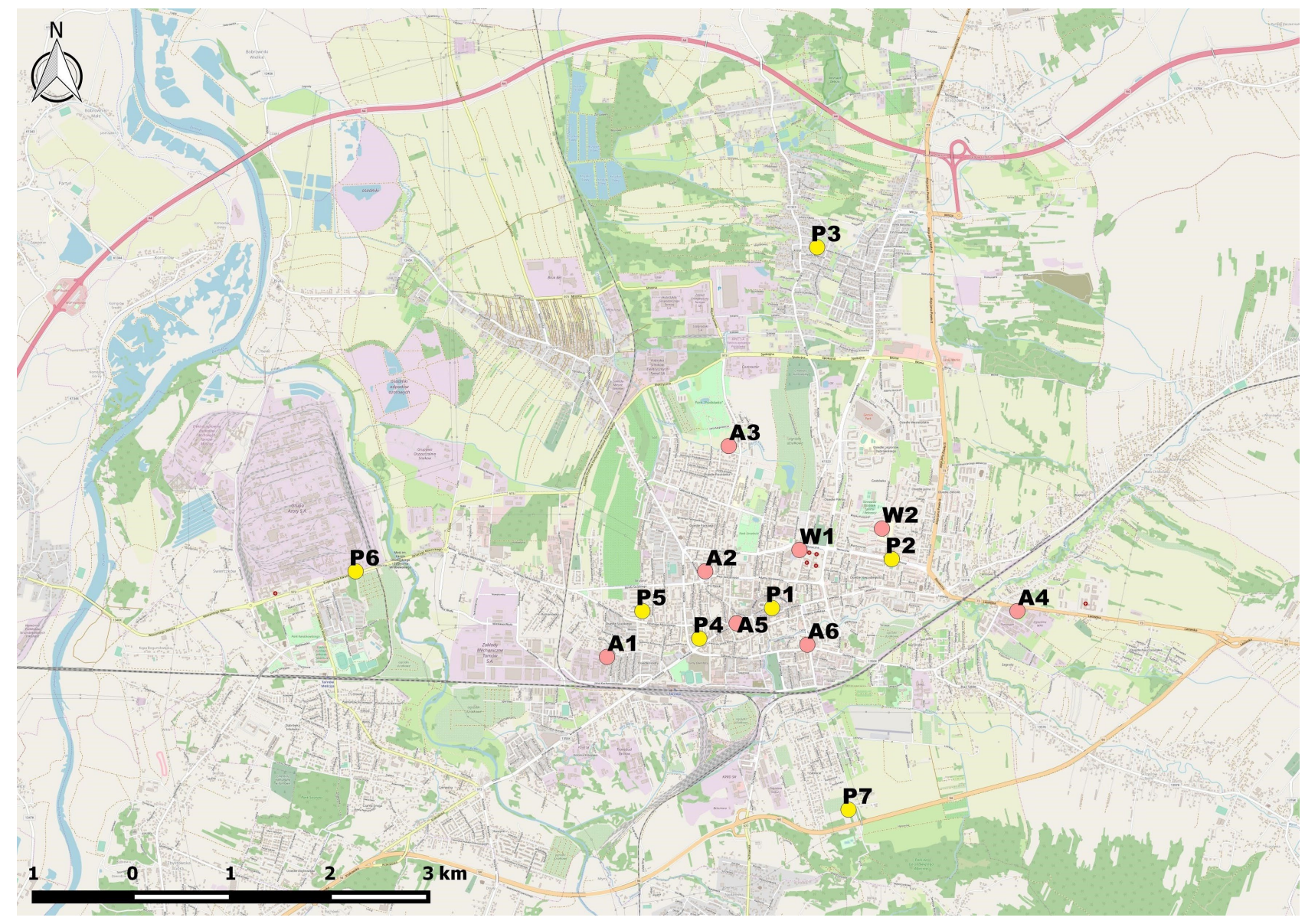

Figure 2. Map of Tarnów City and measurement points localization (the basic map was downloaded from http://geoserwis.gdos.gov.pl) 


\section{The average meteorological data during investigated period}

In Tarnów City the typical wind rose is like this showed on Figure 3, mainly wind comes from west and it brings air pollution from Kraków agglomeration and even from Silesia region - inflow pollution, mainly particulate matter (Fig. 3).

\section{Experimental data}

Networks measurement points localization

The localization of detectors in Tarnów City as a part of Airly network (A1-A6), stations belonging to State Environmental Monitoring System network and manual measurement points illustrates Figure 4. The names and GPS coordinates for all measurement points are given in the Table 1 .

Table 2. Average meteorological data for Tarnów City noted during measurements

\begin{tabular}{|c|c|c|c|c|c|}
\hline Data & $\begin{array}{c}\text { Temperature } \\
{\left[{ }^{\circ} \mathrm{C}\right]}\end{array}$ & $\begin{array}{c}\text { Pressure } \\
{[\mathrm{hPa}]}\end{array}$ & $\begin{array}{c}\text { Relative humidity } \\
{[\%]}\end{array}$ & $\begin{array}{l}\text { Wind force } \\
{[\mathrm{km} / \mathrm{h}]}\end{array}$ & $\begin{array}{c}\text { Wind direction } \\
{\left[^{\circ}\right]}\end{array}$ \\
\hline \multicolumn{6}{|c|}{ 18.02.2019 } \\
\hline 8 a.m. & 0 & 1024 & 88 & 0.2 & 233 \\
\hline 12 a.m. & 9 & 1024 & 58 & 2.6 & 238 \\
\hline 4 p.m. & 13 & 1021 & 48 & 4.4 & 120 \\
\hline 8 p.m. & 6 & 1020 & 74 & 2.4 & 134 \\
\hline \multicolumn{6}{|c|}{ 20.02.2019 } \\
\hline 8 a.m. & 4 & 1018 & 87 & 1.9 & 241 \\
\hline 12 a.m. & 6 & 1019 & 74 & 1.9 & 293 \\
\hline 4 p.m. & 7 & 1020 & 60 & 6.5 & 276 \\
\hline 8 p.m. & 5 & 1022 & 66 & 3.7 & 278 \\
\hline \multicolumn{6}{|c|}{ 22.02.2019 } \\
\hline 8 a.m. & -1 & 1024 & 88 & 4.4 & 278 \\
\hline 12 a.m. & -2 & 1031 & 76 & 6.1 & 230 \\
\hline 4 p.m. & -3 & 1034 & 54 & 3.5 & 266 \\
\hline 8 p.m. & -4 & 1038 & 54 & 0.7 & 270 \\
\hline \multicolumn{6}{|c|}{ 24.02.2019 } \\
\hline 8 a.m. & -4 & 1038 & 54 & 8.1 & 274 \\
\hline 12 a.m. & 0 & 1037 & 42 & 6.7 & 242 \\
\hline 4 p.m. & 2 & 1035 & 45 & 7.4 & 212 \\
\hline 8 p.m. & -1 & 1035 & 57 & 5.6 & 260 \\
\hline
\end{tabular}
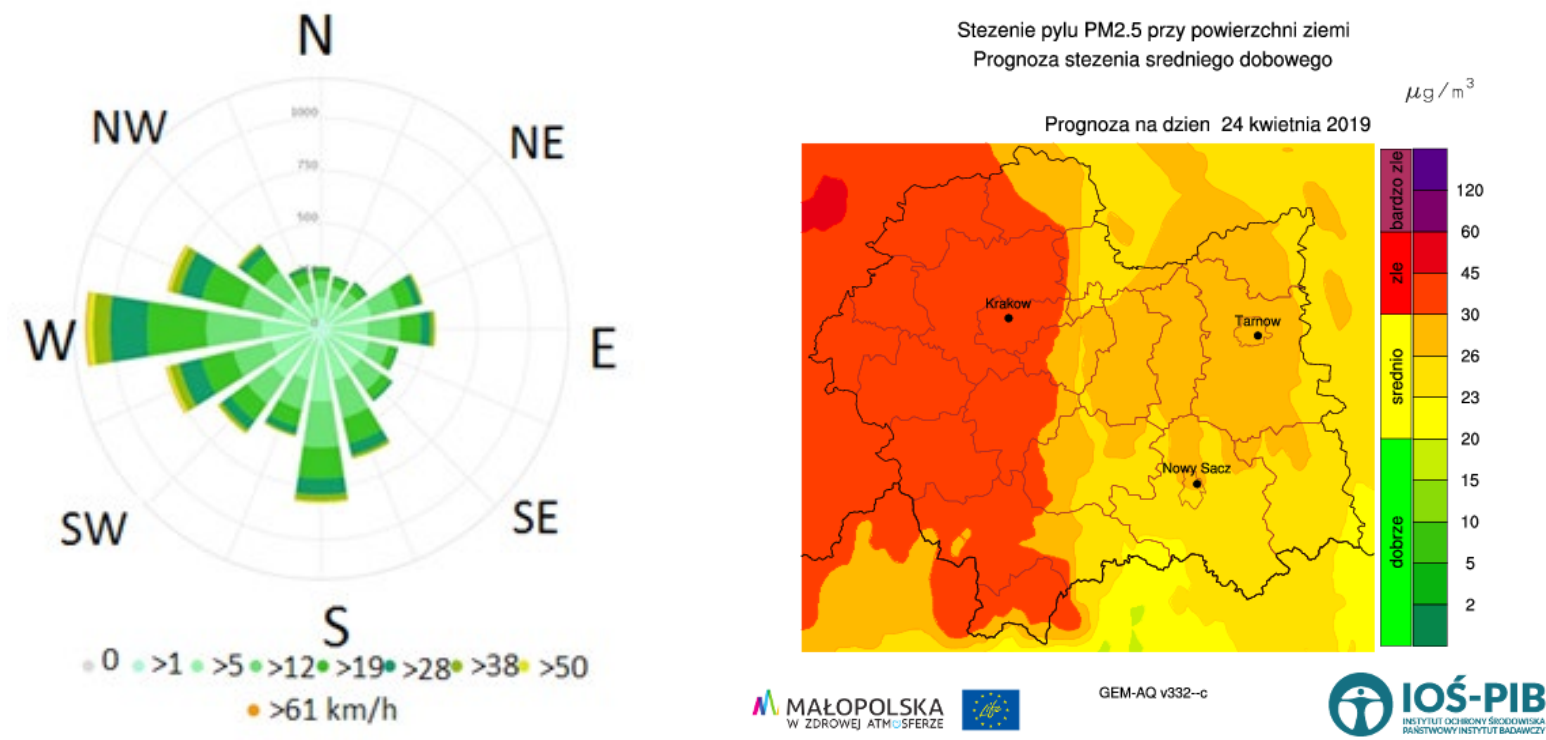

Figure 3. The wind rose for Tarnów City (source: www.meteoblue.com, access 23.04.2019) and prediction map for PM2.5 pollution (source: https://powietrze. malopolska.pl/jakosc-powietrza/, access 23.04.2019) 


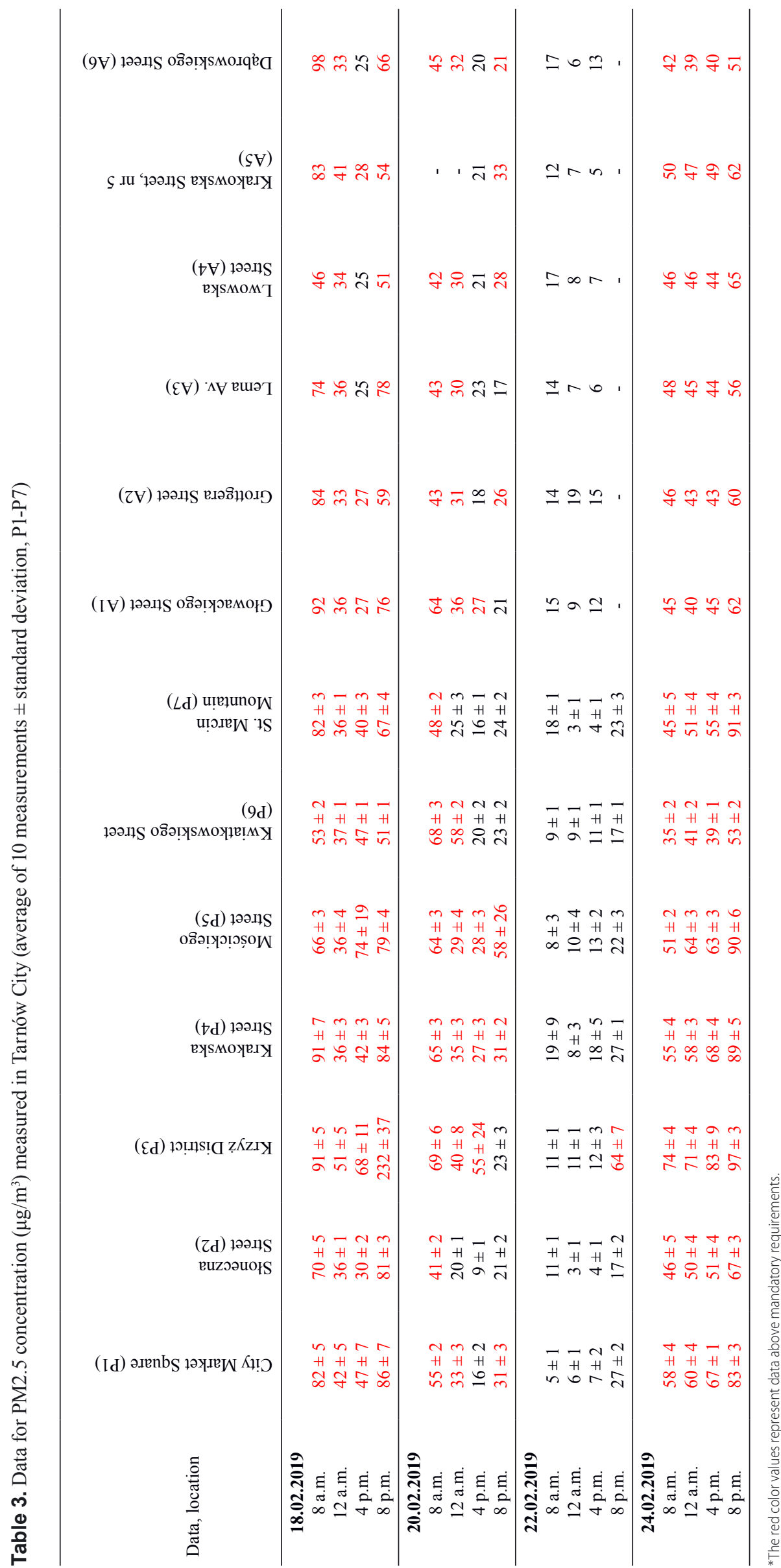




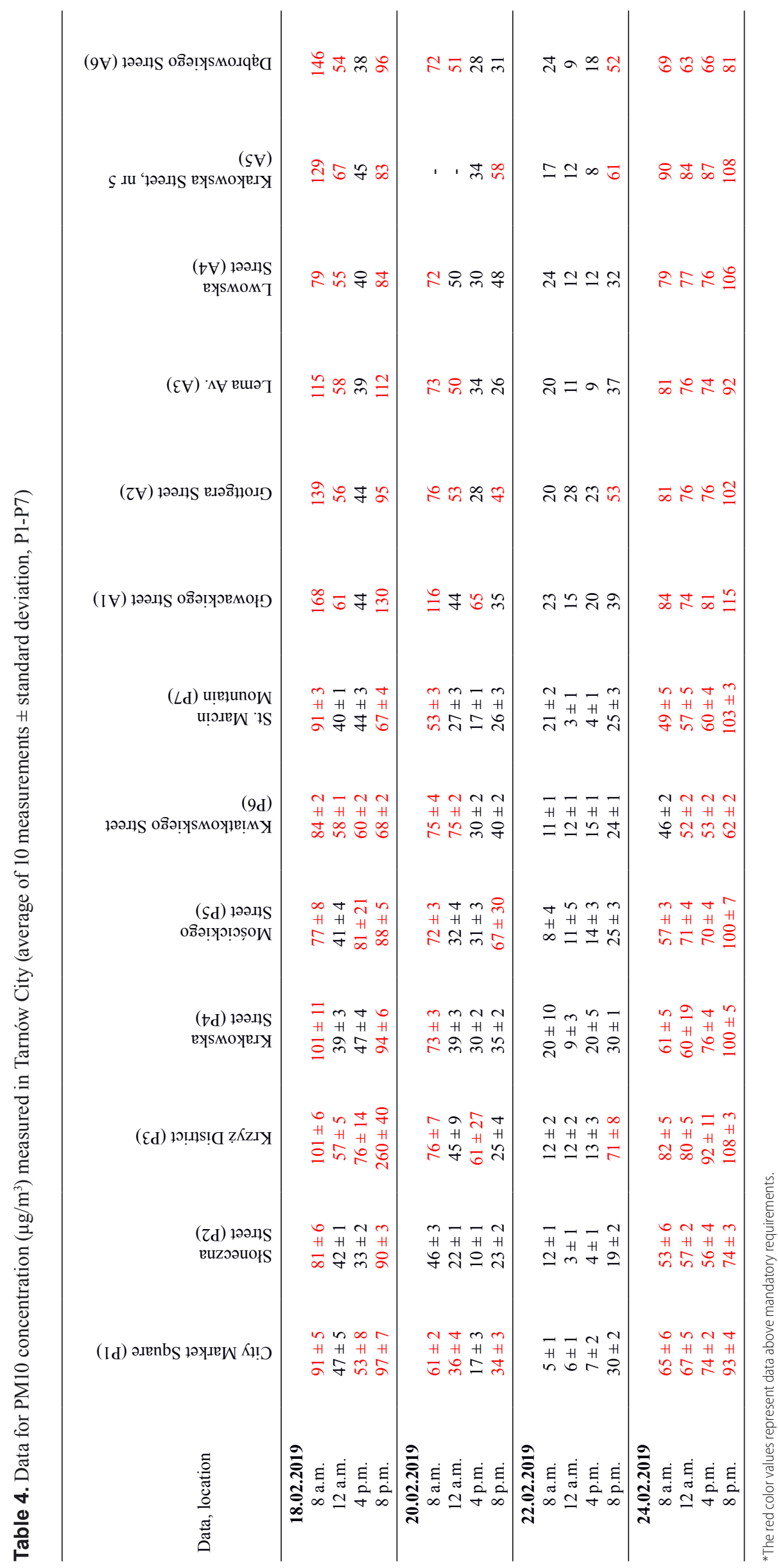


In the same time when group of researchers measured PM10 and PM2.5, data from State Environmental Monitoring System and private sensors network (Airly) were collected.

Data obtained from State Environmental Monitoring System [16] are shown as Figure 4 and 5, both covers data between 18.02.2019 to 24.19.2019. The measurements frequency was 1 hour and data cover daytime and nighttime.

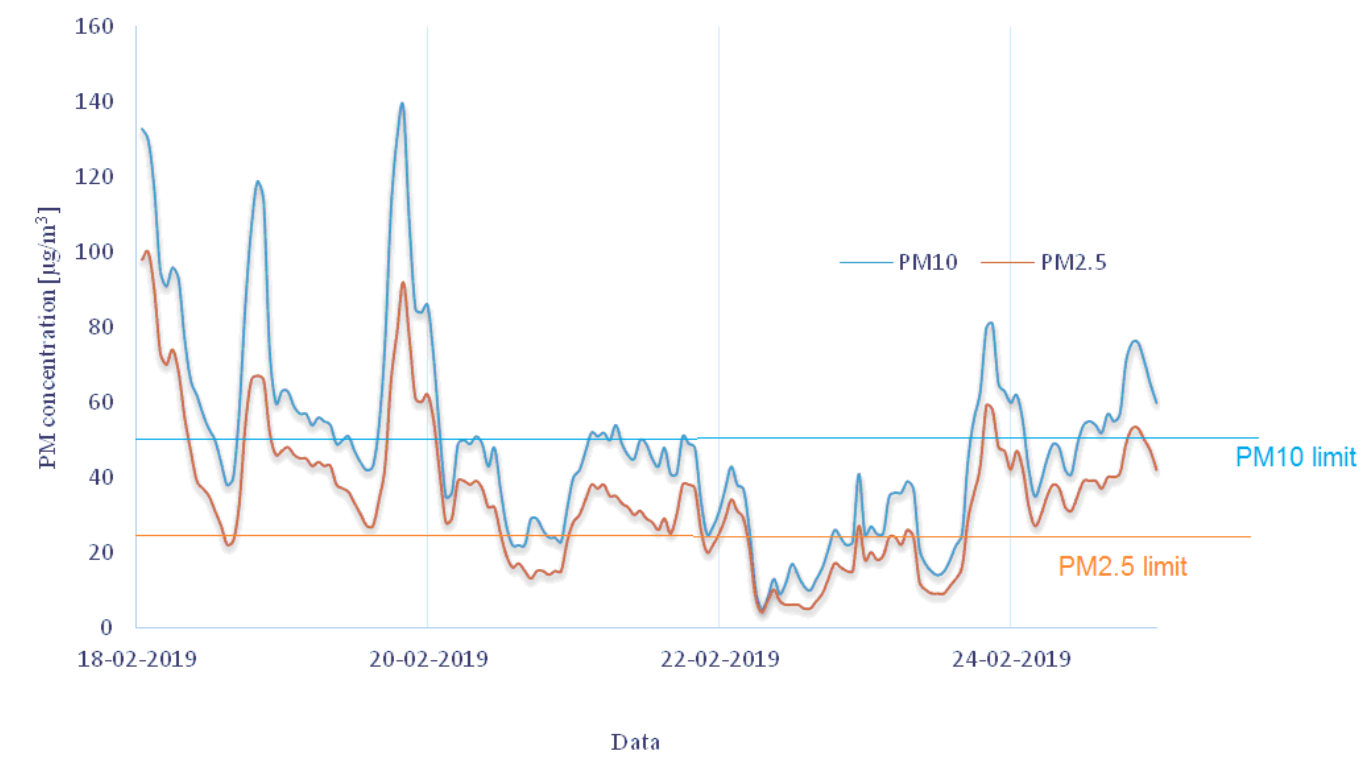

Figure 4. PM2.5 data downloaded from [16] - Tarnów, ks. R. Sitki Str. (W1)

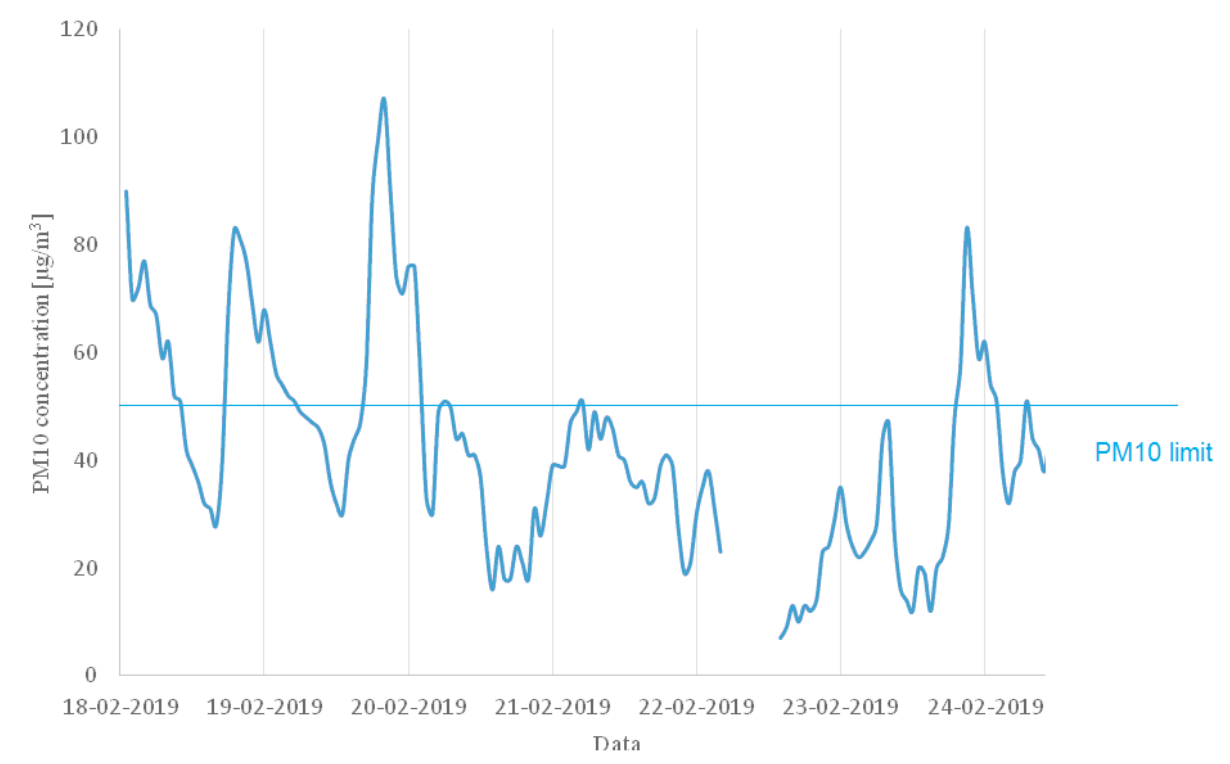

Figure 5. PM10 data downloaded from [16] - Tarnów, Bitwy pod Studziankami Str. (W2)

*Fig. 4 and 5 elaborated based on source: http://monitoring.krakow.pios.gov.pl, access: 26.02.2019 
Final results of investigation presented in Table 5, where collected summarized data for each day of measurements. The investigation delivered information suitable to deduction where air in Tarnów City is the most polluted.

Table 5. Summarized data obtained in conducted experiment $\left(\mu \mathrm{g} / \mathrm{m}^{3}\right)$

\begin{tabular}{|c|c|c|c|c|c|c|}
\hline \multirow{3}{*}{$\begin{array}{l}\text { Data } \\
\text { Point }\end{array}$} & \multirow{3}{*}{ Point description } & 18.02 .19 & 20.02 .19 & 22.02 .19 & 24.02 .19 & Average 18-24.02.19 \\
\hline & & PM2.5 & PM2.5 & PM2.5 & PM2.5 & PM2.5 \\
\hline & & PM10 & PM10 & PM10 & PM10 & PM10 \\
\hline \multirow{2}{*}{ P1 } & \multirow{2}{*}{ City Market Sq. } & $64 \pm 23$ & $34 \pm 16$ & $11 \pm 11$ & $67 \pm 11$ & $44 \pm 28$ \\
\hline & & $72 \pm 26$ & $37 \pm 18$ & $12 \pm 12$ & $75 \pm 13$ & $49 \pm 31$ \\
\hline \multirow{2}{*}{ P2 } & \multirow{2}{*}{ Słoneczna Str. } & $54 \pm 25$ & $23 \pm 13$ & $9 \pm 7$ & $54 \pm 9$ & $35 \pm 25$ \\
\hline & & $62 \pm 28$ & $25 \pm 15$ & $10 \pm 8$ & $60 \pm 9$ & $39 \pm 28$ \\
\hline \multirow{2}{*}{ P3 } & \multirow{2}{*}{ Krzyż Qr. } & $111 \pm 83$ & $47 \pm 20$ & $25 \pm 25$ & $81 \pm 12$ & $66 \pm 53$ \\
\hline & & $124 \pm 93$ & $53 \pm 22$ & $27 \pm 27$ & $91 \pm 13$ & $73 \pm 59$ \\
\hline \multirow{2}{*}{ P4 } & \multirow{2}{*}{ Krakowska Str. } & $63 \pm 28$ & $40 \pm 17$ & $18 \pm 8$ & $68 \pm 15$ & $47 \pm 26$ \\
\hline & & $70 \pm 32$ & $44 \pm 20$ & $20 \pm 9$ & $74 \pm 19$ & $52 \pm 30$ \\
\hline \multirow{2}{*}{ P5 } & \multirow{2}{*}{ Mościckiego Str. } & $64 \pm 19$ & $45 \pm 19$ & $13 \pm 6$ & $67 \pm 16$ & $47 \pm 25$ \\
\hline & & $72 \pm 21$ & $51 \pm 22$ & $15 \pm 7$ & $75 \pm 18$ & $53 \pm 30$ \\
\hline \multirow{2}{*}{ P6 } & \multirow{2}{*}{ Kwiatkowskiego Str. } & $47 \pm 7$ & $42 \pm 24$ & $12 \pm 4$ & $42 \pm 8$ & $36 \pm 19$ \\
\hline & & $68 \pm 12$ & $55 \pm 23$ & $16 \pm 6$ & $53 \pm 7$ & $48 \pm 24$ \\
\hline \multirow{2}{*}{ P7 } & \multirow{2}{*}{ St. Marcin Mt. } & $56 \pm 22$ & $28 \pm 14$ & $12 \pm 10$ & $61 \pm 21$ & $39 \pm 26$ \\
\hline & & $61 \pm 24$ & $31 \pm 16$ & $13 \pm 11$ & $67 \pm 24$ & $43 \pm 29$ \\
\hline \multirow{2}{*}{ A1 } & \multirow{2}{*}{ Głowackiego Str. } & $58 \pm 31$ & $37 \pm 19$ & $12 \pm 3$ & $48 \pm 10$ & $40 \pm 24$ \\
\hline & & $101 \pm 58$ & $65 \pm 36$ & $24 \pm 10$ & $89 \pm 19$ & $70 \pm 44$ \\
\hline \multirow{2}{*}{ A2 } & \multirow{2}{*}{ Grottgera Str. } & $51 \pm 26$ & $30 \pm 10$ & $16 \pm 3$ & $48 \pm 8$ & $37 \pm 20$ \\
\hline & & $84 \pm 43$ & $50 \pm 20$ & $31 \pm 15$ & $84 \pm 12$ & $63 \pm 33$ \\
\hline \multirow{2}{*}{ A3 } & \multirow{2}{*}{ Lema Av. } & $53 \pm 27$ & $28 \pm 11$ & $9 \pm 4$ & $48 \pm 5$ & $36 \pm 22$ \\
\hline & & $81 \pm 38$ & $46 \pm 21$ & $19 \pm 13$ & $81 \pm 8$ & $57 \pm 34$ \\
\hline \multirow{2}{*}{ A4 } & \multirow{2}{*}{ Lwowska Str. } & $39 \pm 12$ & $30 \pm 9$ & $11 \pm 6$ & $50 \pm 10$ & $34 \pm 17$ \\
\hline & & $65 \pm 21$ & $50 \pm 17$ & $20 \pm 10$ & $85 \pm 14$ & $55 \pm 28$ \\
\hline \multirow{2}{*}{ A5 } & \multirow{2}{*}{ Krakowska Str., nr 5} & $52 \pm 24$ & $27 \pm 8$ & $8 \pm 4$ & $52 \pm 7$ & $38 \pm 23$ \\
\hline & & $81 \pm 36$ & 46 & $25 \pm 25$ & $92 \pm 11$ & $63 \pm 37$ \\
\hline \multirow{2}{*}{ A6 } & \multirow{2}{*}{ Dąbrowskiego Str. } & $56 \pm 33$ & $30 \pm 12$ & $12 \pm 6$ & $43 \pm 5$ & $37 \pm 23$ \\
\hline & & $84 \pm 48$ & $46 \pm 20$ & $26 \pm 19$ & $70 \pm 8$ & $56 \pm 34$ \\
\hline \multirow{2}{*}{ W1 } & Sit1: $\mathrm{S}_{\mathrm{t}}$ & - & - & - & - & - \\
\hline & SILI SII. & $72 \pm 35$ & $34 \pm 13$ & $16 \pm 7$ & $59 \pm 12$ & $45 \pm 29$ \\
\hline wa & 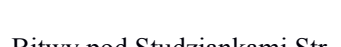 & $45 \pm 20$ & $23 \pm 12$ & $9 \pm 5$ & $42 \pm 7$ & $30 \pm 19$ \\
\hline 10 & 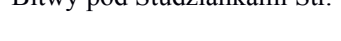 & $53 \pm 24$ & $29 \pm 13$ & $14 \pm 1$ & $55 \pm 11$ & $41 \pm 21$ \\
\hline
\end{tabular}




\section{Conclusions}

The black smog is a situation when a lot of fumes, chemical and physical pollution are emitted to the atmosphere from many emitters. This condition is not enough to occur smog, the another one is atmospheric conditions conducive to this phenomenon. The location of Tarnów City and its geographical specification is not conductive to its high ventilation index during the winter time. Presented research work shows that air quality in Tarnów City is very unhealthy because of particulate matter pollution. In the winter time the main problem is too high concentration of PM2.5, but also PM10 concentration. Those parameters are very frequently exceeded. The worst air quality occurs in the evenings ( 8 p.m.), but in the mornings ( 8 a. m.) air quality is highly polluted too. When air quality in Tarnów City is bad situation concerns all localisations. The similar situation is observed when air quality is good or acceptable. The measurements were conducted during one week only, but it was very special week for air quality measurements. During this week the weather was very unstable. There were days with strong wind when air was clean but 18.02.2019 on the first day and 24.02.2019 the last one day of measurements air quality was very poor. The day 18.02.2019 was relatively warm, but air quality in this time was the worst during measurements period. The worst air quality according to our investigation were observed for Krzyż District and Głowackiego Str. The reason of this situation is a large number of old and inefficient heating systems on those areas. Relatively good air quality was observed in Mościce District (Kwiatkowskiego Str., P6) and near St. Martin Mt. In the past very bad air quality was in location P1 due to very old heating infrastructure there, but after great effort and support from the local magistrate situation is much better now and even better than in many others localizations in the city. This fact shows, that there is possibility to improve situation in Tarnów City and reduce smog nuisance. The main conclusion is that for locations where heat is available from heat plant (is not generated individually by domestic sources), the situation is the most comfortable. Despite this, days when PM10 concentration is higher than 50 $\mu \mathrm{g} / \mathrm{m}^{3}$ and PM2.5 concentration is higher than $25 \mu \mathrm{g} / \mathrm{m}^{3}$ are still very frequent.

Our investigation covered short period, one week only, but it is preliminary study and this important issue will be continued in the future. Nowadays Poland starts very important governmental programme "Clean air" due to which necessity of air improvement and necessity of air monitoring covers many localizations in the city. Another important issue is question about chemistry of particulate matter and its size distribution involving total suspended particulate (TSP), PM10, PM2.5 and PM1 (full fractional analysis).

\section{References}

1. Kosarz M, Satora P. Związki odpowiedzialne za zanieczyszczenie powietrza. Ecological Engineering. 2017;18: 89-95. doi: https://doi.org/10.12912/23920629/79820

2. Zielińska E, Wielgus A, Dreliszak J, Zukow W. Air pollution - selected health effect in Poland. Journal Education, Health and Sport. 2018; 8:641-648. doi: http://dx.doi.org/10.5281/zenodo. 2527086

3. Zhang N, Li M, Qian J, Wang Q, Zhao J, Yang Z, Tian Z, Zhang X, Zuo X, Zhang M, Zhu P, Ye S, Zhang W, Zhang Y, Qi W, Li Y, Zhang Z, Ding F, Gu J, Liu Y, Wei W, Zheng $\mathrm{X}$. Pulmonary arterial hypertension in systemic lupus erythematosus based on a CSTAR-PAH study: Baseline characteristic and risk factor. International Journal of Rheumatic Diseases. 2019;22:921-928. doi: https://doi.org/10.1111/1756$-185 X .13478$

4. Bruckmann P, Hiester E, Kless M, Zetzsch C. Trends of PCD$\mathrm{D} / \mathrm{F}$ and $\mathrm{PCB}$ concentrations and depositions in ambient air in Northwestern Germany. Chemosphere. 2013;93:1471-1478. doi: https://doi.org/10.1016/j.chemosphere. 2013.07.029

5. Szczerbowski R. Wyzwania polskiego sektora wytwórczego do 2030 roku. Zeszyty Naukowe Instytutu Gospodarki Surowcami Mineralnymi i Energii PAN. 2018;102:203-216.

6. Dz.U. $2002 \mathrm{nr}$ 87, poz. 796: Rozporządzenie Ministra Środowiska z dnia 6 czerwca 2002 r. w sprawie dopuszczalnych poziomów niektórych substancji w powietrzu, alarmowych poziomów niektórych substancji w powietrzu oraz marginesów tolerancji dla dopuszczalnych poziomów niektórych substancji.

7. Dz.U. 2012, poz. 1031: Rozporządzenie Ministra Środowiska z dnia 24 sierpnia 2012 r. w sprawie poziomów niektórych substancji w powietrzu.

8. Dz.U. 2018, poz. 1119: Rozporządzenie Ministra Środowiska z dnia 8 czerwca 2018 r. w sprawie dokonywania oceny poziomów substancji w powietrzu.

9. Touray N, Chyc M. Fuel modification based on some metals compounds and their environmental impact. Science, Technology and Innovation. 2018;2:1-6. doi: https://doi. org/10.5604/01.3001.0012.1152

10. Matuszkiewicz JM. Potencjalna roślinność naturalna Polski, IGiPZ PAN, Warszawa, 2008.

11. S.G. 2018: Statistical guidbook 2018. Urząd Statystyczny, Kraków 2018.

12. https://airly.eu/pl/, (access: 1.03.2019).

13. https://pl.wikipedia.org/wiki/Tarn\%C3\%B3w, (access: 29.11.2017).

14. http://geoserwis.gdos.gov.pl, (access 29.11.2017).

15. http:/geoserwis.gdos.gov.pl, (access: 29.11.2017).

16. WIOŚ: http://monitoring.krakow.pios.gov.pl/ (access: 1.03.2019). 